Клімаў I. П.

Мінск

\title{
Стылістыка дапасаваных азначэнняў у Прадмове Васіля Цяпінскага
}

Прысвечаная друкаванаму Евангеллю (каля 1574 г.) Прадмова Васіля Цяпінскага, беларускага пратэстанта і перакладчыка (пра яго жыццё гл.: [Клімаў 2012, 9-25]), - выдатны помнік старабеларускай літаратуры, палымяны публіцыстычны твор. На жаль, Прадмова дайшла толькі ў рукапісе, створаным каля 1580 г. манастырскім перапісчыкам (але, магчыма, паводле друкаванага арыгінала [Клімаў 2005]). Яна падзяляецца на некалькі частак (гл. у дэталях: [Клімаў 2006, 74-82]), даволі адрозных паводле свайго зместу і некаторых стылістычных і моўных рыс.

Важным стылеўтваральным сродкам твора з'яўляюцца азначэнні, якія характарызуюць прыкмету ці якасць аб'екта або яго адносіны да іншых аб'ектаў. У прадмове ӱжываюцца як дапасаваныя, так і недапасаваныя азначэнні, напр.: живого члка ㅇ Азначальнае слова можа характарызавацца як (дзее)прыметнікам ці займеннікам, так і дзеепрыметным зваротам, напр.: свечу, иистостю малженства светячую (145), або нават даданым азначальным сказам, напр.: мдрость, а которая им была праве яко врожоная (92-93) - у гэтым выпадку злучнікі далей не ўлічваюцца. Таксама не ўлічваюцца (дзее)прыметнікі ў прэдыкатыўнай функцыі, напр.: вси

1 Далей лічба ў дужках пазначае нумар радка ў рукапісе твора (лік радкой належыць аўтару дадзенага артыкула, гл. [Клімаў 2006, 74-75]), надрадковыя літары ўносяцца ў радок і бяруцца ў дужкі, напісанні пад цітлам не раскрываюцца, надрадковыя і пунктуацыйныя знакі арыгінала ігнаруюцца. 
рђии ... такъ су(m) попсованы (203-204), аднак улічваюцца дзеепрыметнікі ў паўпрэдыкатыўнай функцыі - у складзе дзеепрыметных ці інфінітыўных зваротаў, напр.: дле дроуку и потребъ тому належачи(x) (47-48), мнимае(m) в на(с) бъl(m) што выступно(г)[о] (218). Дапасаванае азначэнне можа з'яўляцца, у сваю чаргу, галоўным кампанентам іншага словазлучэння - калі мае пры сабе залежны кампанент, напр.: у нам недалеких влохов... (155). У творы пануюць дапасаваныя азначэнні, і дадзеная праца абмежавана разглядам толькі гэтых канструкцый.

Часам некаторыя адносныя прыметнікі (і дзеепрыметнікі) могуць выступаць у фразе як фармальны субстантыў, калі азначальнае слова пры такім азначэнні прапушчана, але з кантэксту зразумелае і лёгка аднаўляецца (эліпсіс), напр.: двема єзыюьь, зара(з) и слове(н)ски(м) и при не(м) тут жо роускимъ. а то набо(л)шиі и слове(н)скимъ (63-65), не новоє што, але $и(x)$ же властноє (68). Такія формы лічацца азначэннямі, калі ў межах сказа маецца для іх адпаведнае азначальнае слова. Ва ўсіх астатніх выпадках прыметнікі адносяцца да азначэнняў толькі паводле сінтаксічнай функцыі. Напрыклад, прыметнік побожный будзе з'яўляцца азначэннем у прыкладзе побо(ж)ного чито(л)ника (217), але субстантывам без азначальнага слова (вси(x) побо(ж)ныз (x) ... просимъ, 224), як субстантыу - толькі богобойный $(14,25,85)$, але як прыметнік - богобоиному илвку $(177)$, як субстантыў учоный (41) (як прыметнік - 70, 89, 117), толькі як субстантыў духовный (99).

Тое ж тычыцца і займеннікаў у азначальнай функцыі. Часам некаторыя займенікі (иный, который) могуць выступаць у фразе як фармальны субстантыў, калі азначальнае слова пры такім азначэнні прапушчана, але 3 кантэксту зразумелае і лёгка аднаўляецца (эліпcic): по всђ (x) ирква(x) сербски(x), моско(в)ски(x), волоски(x), булъга(p)ски $(x), x a(p) в и к и(x), i$ иньл(x) <царквах> (122-123), з папою римски(м), и зъ иньми <асобамі> (136-137), оучителе(u) свои(x) ... $\omega(m)$ иньл $(x) \omega(m)$ делили (142-143), они [славяне] ... мимо иньл $(x) \ldots$ были ... оздобени (149-151). Такія формы лічацца азначэннямі.

Усяго $\ddot{\mathrm{y}}$ творы зафіксавана 167 азначальных слой (назоўнікай і займеннікаў, аднародныя назойнікі рэгістраваліся толькі па адным са сваіх кампанентаў, напр.: вси(м) народо(м), и вера(м) 144, владыкъ u учителеи ваших, 182). Для іх азначэння было выкарыстана:

- прыметнікаў - 82, якія у суме даюць 149 ўжыванняў (найбольш частыя - божий (18), словенский (7), великий (5), зачный (5), греческий (4), давний (4), роуский (4), влас(m)ньий/влосньий (4) і інш., т. ч. 
56 прыметнікаў (!) ужыта ўсяго па 1 разе), у т. л. 5 азначэнняў, якія маюць пры сабе іншыя залежныя кампаненты: синоды ... памети годные (136-136), вечное памети годныи приклад (147-148), оных часов наоученших народов (152), у нам недалеких влохов... (155), члка ... собе знаємого (207-208), і 9 азначэнняў, што маюць пры сабе ўзмацняльныя часціцы або прыслоўі (толькі ў прэпазіцыі): такъ, исте, неледа, многокротъ, ани (37, 41-42, 70, 77, 86-87, 117-118, 149-150, 159-160, 230-231); пры гэтым амаль усе прыметнікі узжыты ў поўнай (членнай) форме (выключэнні: слово боже 160, слово бже 163);

- дзеепрыметнікаў - 22, ужытых у сукупнасці 26 разоў (учоный (4), ведомьй, видомьий, наданьй, поданьий і інш.) $)^{2}$, у т. л. 8 у складзе дзеепрыметных зваротаў $(32-33,47-48,143-144,145,156-157,184,189-190$, 231), таксама толькі ў поўнай (членнай) форме;

- займенікай - 16, ужытых у сукупнасці 137 разой (такой (10), иныцй (9), той (8), весь (8), тотъ (6), оный (6), жадный 'ніякі, ніхто' (2), самый (2), который, некоторый, многий і інш.), з якіх 83 разы прыпадае ўсяго на 5 займеннікаў, што выражаюць адносіны прыналежнасці (прыналежныя свой (29), мой (9), вашъ (11), нашъ (7) і формы ўскосных склонаў асабовага займенніка (ее, его; ихъ з 23 выпадкамі), ужытыя разам 27 разой);

- лічэбнікаў - гэта фактычна толькі лічэбнік одинъ (2) у функцыі азначэння (у помніку ён выкарыстоўваецца таксама і як лічэбнік, і як часціца).

Азначэнні - займеннікі, (дзее)прыметнікі - па тэксце размеркаваны больш-менш раўнамерна, што сведчыць пра даволі вобразны характар усяго твора. Прыблізна раўнамерна размеркаваныя па тэксце помніка і азначальныя словы.

Выразнай асаблівасцю Прадмовы з'яўляецца частае ӱжыванне некалькіх азначэнняў пры адным азначальным слове. Усе азначэнні помніка $\ddot{y}$ гэтых адносінах можна падзяліць на адзін к в ы я, калі пры азначальным слове выступае толькі адно азначэнне (напр.: фальь своєе 12, ку фале бжиєи, 61-62), і мн ожныя (падвойныя ці рэдка патройныя), калі азначальнае слова мае пры сабе больш за адно азначэнне (напр.: зачнои монархии словенскои, 24-25). Са 167 азначальных слой 54 (у аснойным напачатку і ӱ сярэдзіне помніка) маюць пры сабе больш за адно азначэнне. Множныя азначэнні складаюцца або толь-

2 У марфалагічных адносінах гэта ў асноўным пасіўныя дзеепрыметнікі з суф. -ні -м-, з суф. -и- адзначана 5 формаў, з -и- адна. 
кі з адных прыметнікай (напрыклад, 9 азначальных слоў маюць пры сабе аднародныя прыметнікі), або з адных займенікай (напр.: тому народу вашому 180), або з прыметнікай і займеннікаў, або з адных дзеепрыметных зваротаў, або з дзеепрыметнага звароту і займенніка ці прыметніка.

Ужыванне некалькіх азначэнняў пры адным азначальным слове надае яму больш рознабаковую характарыстыку. Так, у выразе оная ясная их ... мдрость (91-92) паняцце мудрасці ахарактарызавана па некалькіх параметрах: а) пэўная (ці старажытная) мудрасць (оная), б) уласцівая руськаму народу $(u x ъ)$, в) якасць гэтай мудрасці (яcная). Аднак часам множныя азначэнні выконваюць хутчэй нейкую стылістычную функцыю. Гэта назіраецца у выпадках, калі азначэнні не выражаюць істотную або зайважную розніцу у семантыцы у прыкмеце ці якасці азначальнага слова, да якога яны адносяцца. Так, у выразе их власньлм езылком роускимъ (33-34) відавочна семантычная збыткойнасць азначэнняў: 3 папярэдняга кантэксту зразумела, што езькъ русъкий звязаны з народомъ руськимъ, займеннік ихъ дублюе гэтую сувязь, а прыметнік власный паўтарае сэнс абодвух гэтых азначэнняў. Тым не менш, у кантэксце ўсёй фразы: [евангелия - жан. р.] которая з словенского абы имъ, теж и их власныл езыком роускимъ в дроукоу вылила (33-34) становіцца зразумелым, што паўтор азначэння руський неабходны для супрацьпастаўлення у межах фразы з азначэннем словенский, тады як іншыя азначэнні характарызуюць крыху інакшыя параметры аб'екта - прыналежнасць (uxъ) і якасць (власныци). Тым не менш, характарыстыка гэтая малаістотная і фактычна збыткойная, хаця і апрайданая ў пэўных стылістычных мэтах, а менавіта - для падкрэслення і ўзмацнення (шляхам кантрасту) семантыкі прыметніка словенский, які выступае ў межах фразы (у каардынатах 'свой' - 'чужы').

Такіх збыткойных спалучэнняў у помніку налічана каля двух дзясяткай (некалькі выпадкаў могуць быць спрэчнымі). Відаць, аўтар Прадмовы лічыў множныя азначэнні важным элементам свайго стылю, а сэнсавую збыткойнасць многіх 3 ix разглядаў як неабходную для дасягнення сваіх стылістычных мэт. Так, аб'екту ў словазлучэнні писмь своих оних (133) даецца характарыстыка і паводле прыналежнасці, і паводле указальнасці (калі не асобнае дадатковае значэнне 'даўні, старажытны'), тады як адзінкавыя азначэнні (напр.: оныл словян, 106) здольныя даць аб'екту толькі адну характарыстыку. Частае ўжыванне множных азначэнняў надае твору крыху плеанастычны характар. Аўтар, відаць, імкнуйся да трывалага замацавання тых ці ін- 
шых азначальных слоў (пэўных вобразаў або паняццяй) у памяці сваёй аўдыторыі.

Іншая асаблівасць Прадмовы - частае ўжыванне займеннікай у функцыі азначэння. Колькасць нават адзінкавых азначэнняў, выражаных займеннікам, у помніку даволі значная - 47 (а выражаных прыметнікам - 56). Так, у адной з частак твора (радкі 165-198, амаль 300 слоў) 17 азначальных слоў маюць пры сабе 20 займеннікаў (14 з іх прыналежныя) і толькі 16 прыметнікаў. Такое частае ўжыванне займеннікаў нярэдка стварае ўражанне збыткойнасці, калі не сэнсавай, то сінтаксічнай. Так, у фразе такъ яко они вси везде во всих своих ирквах чтоут и мают (66-67) звяртае на сябе ўвагу збег займеннікаў у адной фразе. Хаця $\breve{y}$ сэнсавых адносінах злучэнні они вси везде i во всих своих ирквах кожнае паасобку не збыткоўныя па семантыцы (хутчэй яны дапаўняюць характарыстыку аб’екта), аднак менавіта іх спалучэнне побач у адной фразе стварае ўражанне збыткойнасці. Падобная плеанастычнасць, відаць, таксама была стылістычнай задачай Цяпінскага, які такім чынам імкнуўся ўзмоцніць афектыўнасць свайго твора.

Частае ўжыванне у помніку аднолькавых займеннікай пры розных азначальных словах спрыяе дыверсіфікацыі, разнастайнасці значэнняў. Так, займеннікі оньии, оная, оное (ад'ектыўныя) і онъ, она, оно (іменныя), з'яўляючыся ўказальнымі (напр.: оных словян, 106, онь сино$\partial b l, 136)$, набываюць у складзе множных азначэннях яшчэ і значэнне пэўнасці: оньмъ давним вђкомъ (28-29), оная ясная ... мдрость (91-92), оньи справедливыл судя (215) ці значэнне 'даўні, старажытны': оных часов (152), сюды, магчыма, таксама писмь своих оних (133). Тым не менш, для старабеларускай мовы яны ўсё ж з'яўляюцца даволі архаічнымі, паколькі адсутнічаюць у сучаснай беларускай мове (яе формы кшталту вон 'ён' / ён не ідуць тут ў лік). Магчыма, пашырэнне $\ddot{y}$ XVI ст. (у т. л. і ӱ Прадмове) яны здабылі пад польскім уплывам. Займеннікі такой, такая, такое (ад'ектыўныя) і momъ, ma, mо (іменныя) нават у якасці адзінкавых азначэнняў не толькі ўказваюць на раней згаданае $\breve{y}$ кантэксце (напр.: за такою неволею, 102-103) ці канкрэтызуюць (напр.: тот муж, 125, на тот час, 201), але і набываюць адцень узмацняльнасці: $u$ такою невдячностью ... платити хотћли (55-57). Апошняе значэнне асабліва выразна і часта выяўляецца $\breve{y}$ выпадку множных азначэнняў: такую казнь бжію (85), таких панов значных (87), таким гоиньл даромъ (150), nо таких фалебных предках (167). Пры наяўнасці суадноснага злучніка два значэнні, указальнасці і уззмацняльнасці, могуць спалучацца 
ў адным займенніку: такая оплаканая неумеєтность пришла. же вжо некоториє и писмом се своим ... встыдают (94-96).

Зразумела, што падобныя функцы могуць выконваць таксама прыметнікі, аднак іх значэнне больш спецыфічнае і выразнае параўнальна са значэннем займеннікаў. Гэта ўскладняе выкарыстанне прыметнікаў для стылістычных мэтаў (напрыклад, дзеля стварэння плеанастычнага эфекту), паколькі тады даводзіцца ўлічваць яшчэ і семантычны аспект. Займеннікі ж больш абагульненыя па сваёй семантыцы, больш «невыразныя» і «сцёртыя», і таму больш падыходзяць для вырашэння стылістычных задач.

Праілюстраваць гэта можна на прыкладзе займеннікаў, што выражаюць адносіны прыналежнасці (гэта не толькі прыналежныя займенікі, але і формы 3-й асобы асабовага займенніка адз. і мн. л. - ezo, uxъ і пад.). Такія адносіны паслабляюцца, фактычна сціраюцца $\ddot{y}$ выпадку частага паўтарэння гэтых займеннікаў у адносна невялікім кантэксце, у выпадку твора Цяпінскага - у межах адной фразы (з адным прэдыкатыўным цэнтрам), напр.: гды ж простота члвка бедного посполитого ... за вами идет в тую потребу отчизнь вашое в простоту грубую, про недостаток науки брати вашое. прикладом своим милосерным (170-175), тому народу вашому неумеєтностью заведеному и утрапеному, допомагаючи. митрополита вашого, владькъ и учителеи ваших до того прозбами вашими вели, жебъ... (180-183). У гэтых прыкладах прыналежныя займеннікі выкарыстаны не столькі дзеля таго, каб выразіць адносіны прыналежнасці (збыткойнасць такога выражэння відавочная), колькі ў пэўнай стылістычнай функцы - для анафары. Цяпінскі, відаць, з дапамогай гэтых займеннікаў імкнуўся $\ddot{y}$ такіх месцах ўзмоцніць эфект свайго маўлення.

Частотнасць ужывання займеннікаў у функцыі азначэння таксама можа служыць пэўным стылістычным задачам. Так, у адной з сэнсавых частак твора (радкі 199-216) яе пачатак (радкі 199-201) і канец (радкі 210-216) маюць 8 азначальных слоў, якія азначаны 7 займеннікамі (4 з якіх - прыналежныя) і 3 прыметнікамі (прычым 2 з іх адносныя). Але $\breve{y}$ цэнтры гэтай часткі змешчана рытарычнае разважанне, якому ўласцівы іншыя рысы: 9 азначальных слоў, азначаных толькі 2 займеннікамі (1 з іх - прыналежны) і аж 9 якаснымі прыметнікамі і дзеепрыметнікамі. У выніку, узнікае супрацьпастаўленне вобразнага разважання ў сярэдзіне гэтай часткі яе больш гутарковаму, маўленчаму аздабленню па баках. Аўтар нібы прыцягваў увагу сваёй аўдыторыі да важнай вобразнай інфармацыі. 
Яшчэ адной адметнай стылістычнай характарыстыкай азначэнняў у тэксце помніка з'яўляецца іх пазіцыя адносна азначальнага слова. 3 ліку адзінкавых азначэнняў 55 знаходзіцца ў прэпазіцыі ад яго і 57 постпазіцыі. Множныя азначэнні могуць змяшчацца або толькі ў прэпазіцыі - 28, або толькі ў постпазіцыі - 9, або ў прэпазіцыі і постпазіцыі - 12. Бачна, што для адзінкавых азначэнняў няма розніцы паміж прэ- і постпазіцыяй, тады як множныя азначэнні выразна схільныя да прэпазіцыі. Аднак усе дзеепрыметныя звароты знаходзяцца ў постпазіцыі. Відавочна, што пазіцыя азначэння не звязана 3 яго семантыкай, а гэта значыць, што пазіцыя служыць яшчэ адным стылістычным прыёмам. Падобная прэпазіцыя множных азначэнняў, здаецца, больш уласціва гутарковаму, афектыўнаму стылю маўлення.

Можна зрабіць выснову, што дапасаваныя азначэнні ў тэксце Прадмовы апрача натуральнай вобразнай характарыстыкі выконваюць і пэўныя стылістычныя задачы. Па-першае, аўтар часта ўжывае множныя азначэнні, што спрыяе большай афектыўнасці, пафаснасці твора. Па-другое, у складзе азначэнняў часта выкарыстойваюцца займеннікі (нярэдка - для выражэння адносін прыналежнасці) у мэтах стварэння плеаназму ці анафары, што падвышае рытарычнасць твора, запамінальнасць яго асобных выразаў і вобразаў. Па-трэцяе, і множныя дапасаваныя азначэнні $\ddot{y}$ помніку нярэдка ўжываюцца 3 плеанастычным эфектам, што сведчыць пра іх стылістычную функцыю. Паводле ўсіх гэтых параметраў твор Цяпінскага можна ахарактарызаваць фактычна як прамову, ці як тэкст, у якім аўтар ужываў аратарскія прыёмы і сродкі. 3 аднаго боку, гэта пацвярджае высновы, зробленыя раней на падставе аналізу кампазіцыі твора, пра яго казальную прыроду, блізкасць да вуснай прамовы [Клімай 2006, 83-85]. 3 другога боку, гэта сведчыць пра значны вопыт Цяпінскага як прамоўцы - нават у пісьмовы тэкст сваёй Прадмовы ён прыносіӱ многія аратарскія прыёмы, звязаныя з вусным маўленнем. Такім ускосным чынам можна бадай пацвердзіць выказныя раней здагадкі пра тое, што Цяпінскі быў у сваёй пратэстанцкай грамадзе казнадзеем [Клімаў 2012, 29].

\section{Літаратура}

Клімаў І. П., 2005, Пьттанне паходжання $i$ складу «Прадмовы» В. Цяпінскага уั святле кніжнай культуры XVI cm., [у:] Матэрыяльг Трэціх міжнародных кнігазнаўчьх чытанняў «Кніга Беларусі. Повязь часоў» (Мінск, 16-17 верасня 2003 г.). Мінск, с. 118-131. 
Клімаў, І. П., 2006, Змест, кампазіџыл $і$ жанр «Прадмовы Васіля Цяпінскага», [у:] "Беларускі археаграфічны штогоднік", вып. 7, c. $73-94$.

Клімаў, І. П., 2012, Евангелле ў перакладзе Васіля Цяпінскага, Мінск.

STRESZ C Z E N I E

\title{
STYLISTYKA OKREŚLEŃ POZOSTAJĄCYCH W STOSUNKU ZGODY W PRZEDMOWIE BAZYLA TIAPINSKOGO
}

Artykuł analizuje częstotliwość i funkcje stylistyczne określeń zgody w znanym tekście starobiałorskim z drugiej połowy XVI wieku - Przedmowa białoruskiego protestanta Bazyla Tiapinskogo dotycząca przetłumaczonej i opublikowanej przez niego Ewangelii. Autor artykułu formułuje wniosek, że środki stylistyczne w nim omówione odzwierciedlają styl Przedmowy i wybrane techniki wypowiedzi ustnej jej autora.

Słowa kluczowe: literatura starobiałoruska, Ewangelia, przedmowa, określenia zgody, stylistyka.

\author{
S U M M A R Y \\ STYLISTICS OF CONCORDANT ATTRIBUTES \\ IN THE PREFACE OF BASIL TYAPINSKY
}

The article analyzes frequency and stylistic functions of the concordant attributes in famous text of the Old Belarusian literature of the second half of the 16th c. - the preface of the Belarusian Protestant Basil Tyapinsky, dedicated to the Gospel translated and printed by him. The conclusion of the analyses is that the rhetorical devices examined in the article reflect a speech style of the preface and some oral techniques of its author.

Key words: Old Belarusian literature, Gospel, preface, concordant attributes, stylistics. 